\title{
Infectivity of Mikrocytos mackini, the causative agent of Denman Island disease in Pacific oysters Crassostrea gigas, to various species of oysters
}

\author{
S. M. Bower*, D. Hervio, G. R. Meyer \\ Department of Fisheries and Oceans, Biological Sciences Branch, Pacific Biological Station, Nanaimo, British Columbia, \\ Canada V9R 5K6
}

\begin{abstract}
In addition to Crassostrea gigas, Mikrocytos mackini Farley 1988, a pathogenic intracellular protistan of unknown taxonomic affiliations, produces disease and mortalities in other species of economically important oysters (Crassostrea virginica. Ostrea edulis and Ostrea conchaphila). Preliminary evidence suggests that these alternate species may be more susceptible to infection and the resulting disease than the usual host $C$. gigas. $M$. mackini isolated from $C$. virginica and $O$. edulis were infective for oysters. Warm temperatures (above $15^{\circ} \mathrm{C}$ ) prevented the development of $M$. mackini in C. gigas, C. virginica and $O$. edulis.

KEY WORDS: Mikrocytos mackini Crassostrea gigas - Crassostrea virginica - Ostrea edulis - Ostrea conchaphila Protista. Denman Island disease Infectivity
\end{abstract}

\section{INTRODUCTION}

In British Columbia, Canada, Denman Island disease, caused by Mikrocytos mackini (Farley et al. 1988), can account for about $30 \%$ mortality in marketsized Crassostrea gigas (Pacific oysters) on certain beaches in the spring of some years (Bower 1988). $M$. mackini is a tiny protistan (about $2 \mu \mathrm{m}$ in diameter) of unknown taxonomic affiliations that inhabits the vesicular connective tissue cells of its host. Infection with this parasite often results in the development of greenish coloured lesions (pustules, up to $1 \mathrm{~cm}$ in diameter) in the oyster tissues, and the parasite can be transmitted directly between oysters. To date, all infected oysters obtained from the field were either collected off a beach or, if from hanging culture, had been held on the beach during the spring months. Thus, natural transmission is known to occur on certain beaches in British Columbia but transmission between oysters being cultured only via suspension techniques has not yet been verified.

\footnotetext{
•E-mail: bowers@pbs.dfo.ca
}

Prior to this study, Mikrocytos mackini was only known in Crassostrea gigas from British Columbia. Because $C$. gigas is an important species to shellfish aquaculture in many countries around the world, concern was raised about the potential risks involved with the inadvertent introduction of this parasite to other countries in conjunction with global transfers of $C$. gigas. Thus, it was important to ascertain the susceptibility of other species of oysters to this parasite and the disease it causes.

Although Mikrocytos mackini could be transmitted between Crassostrea gigas by cohabitation in the laboratory and by incubation in a slurry of homogenized diseased oysters (Quayle 1961), these methods of exposure are unreliable for testing the host specificity of M. mackini. It is impossible to determine if each oyster used in the experiment had been exposed (or remained closed for the exposure period) and if the extent of exposure was similar for all exposed oysters. Also, these methods of exposure usually had a long prepatent period ( 3 to $6 \mathrm{mo}$ ) and resulted in prevalences of infection less than 50\% among exposed oysters. Recently, techniques were developed to isolate viable and infective $M$. mackini from heavily 
infected oysters dying from Denman Island disease and the parasite could reliably be transmitted between C. gigas by inoculation of the isolate into the adductor muscle of uninfected oysters (Hervio et al. 1996).

In the present study, inoculation of Mikrocytos mackini isolates was used to assess the infectivity of $M$. mackini to other economically important species of oysters currently available in British Columbia. This procedure was also used to determine if $M$. mackini isolated from alternate species of oysters were infective and if warm temperatures impeded the development of $M$. mackini in alternate species as in the usual host, Crassostrea gigas. In addition to this artificial mechanism of assessing susceptibility, results were confirmed by exposing the various species of oysters to natural transmission in the environment.

\section{MATERIALS AND METHODS}

Oysters. Large Crassostrea gigas [122.2 $\pm 25.0 \mathrm{~mm}$ (mean \pm standard deviation) in shell length, $n=213$, and over 2 yr of age], small C. gigas $[59.3 \pm 8.9 \mathrm{~mm}$ in shell length, $\mathrm{n}=59$ at $8.5 \mathrm{mo}$ and $64.3 \pm 8.9 \mathrm{~mm}, \mathrm{n}=43$ at 12 mo of age), Crassostrea virginica (eastern oysters, $75.1 \pm 11.5 \mathrm{~mm}$ in shell length, $\mathrm{n}=186$ ), Ostrea edulis (flat oysters, $79.1 \pm 8.7 \mathrm{~mm}$ in shell length, $\mathrm{n}=160$ ), and Ostrea conchaphila (the only species of oyster indigenous to British Columbia, $41.8 \pm 5.2 \mathrm{~mm}$ in shell length, $\mathrm{n}=67$ ) were obtained from various locations in southern British Columbia. Oysters that were not used in experiments within $2 \mathrm{wk}$ of collection were held in lantern nets suspended in Departure Bay, Nanaimo, British Columbia. The holding period varied between 14 and 24 mo for the large $C$. gigas and was less than 5 mo for all other species including the small $C$. gigas. In the laboratory, groups of 60 or fewer oysters were held in $50 \mathrm{l}$ tanks supplied with flowing seawater (2 to $41 \mathrm{~min}^{-1}$ ) of ambient salinity (28 to 30 parts per thousand) and temperatures of about $10^{\circ} \mathrm{C}$ unless otherwise indicated. Experimentally exposed and control oysters were always held in separate tanks. In the laboratory, oysters were examined for mortalities and fed 5 times per week with a variety of cultured algae [i.e. each tank


Chaetoceros gracilis (clone NRC 108), Isochrysis sp. from Tahiti (clone Bigalow CCMP 1324), or 3H Thalassiosira pseudonana (clone Bigalow CCMP 1335)].

Mikrocytos mackini isolation and transmission by inoculation. For all laboratory transmission experiments, oysters were exposed to Mikrocytos mackini by inoculation. Although $M$. mackini originated from Crassostrea gigas stocks cultured in British Columbia, the isolates used in these studies had been maintained in the laboratory for up to 2 yr by passage (inoculation.) between $C$. gigas every 6 to 8 wk with passage to other species of oysters for experimental purposes. The parasite was isolated from experimentally infected oysters as described previously (Hervio et al. 1996). Briefly, labial palps and adductor muscle from heavily infected oysters were excised, rinsed in filtered seawater (FSW at $0.22 \mu \mathrm{m}$ ) supplemented with $1 \%$ Tween 80 (FSWT), homogenized, sieved successively through $200,100,60$, and $20 \mu \mathrm{m}$ nylon meshes and centrifuged for $30 \mathrm{~min}$ at $2000 \times \mathrm{g}$. The resulting pellet was either: (1) washed twice in FSW (resuspension followed by centrifugation) to remove the Tween; or (2) resuspended in FSWT, layered onto a 15 to $30 \%(\mathrm{w} / \mathrm{W})$ sucrose/FSWT gradient, centrifuged as above, the sucrose solution decanted and the pellet washed once in FSW. For both methods, the washed pellet was resuspended in a desired volume of FSW. The relative intensity of $M$. mackini in the inoculum was determined from a smear prepared with about $20 \mu \mathrm{l}$ of the inoculum. The smear was air dried, and fixed and stained with a commercial modification of a WrightGiemsa staining procedure (Diff Quick Stain Set, Baxter Healthcare Corporation, McGraw Park, IL, USA) following the manufacturers protocol. The average number of $M$. mackini per field (200 $\mu \mathrm{m}$ in diameter at $1000 \times$ magnification) was determined and was used as the relative measure of intensity. For details on the species of oyster from which $M$. mackini was obtained and the relative intensity of $M$. mackini in the inoculum see Tables $1 \& 2$.

Oysters exposed to Mikrocytos mackini by inoculation and control oysters, inoculated with an equivalent volume of FSW, were prepared for inoculation by mechanically grinding the edge of both valves at the level of the adductor muscle to make a small aperture into the mantle cavity. To relax the adductor muscle to facilitate inoculation, these oysters were immersed in an anesthetic solution of $7 \%$ magnesium chloride hexahydrate $\left(\mathrm{MgCl}_{2} \cdot 6 \mathrm{H}_{2} \mathrm{O}\right)$ in seawater for 3 to 5 h. prior. to inoculation. All oysters were inoculated into the adductor muscle using a 25 gauge $1 \frac{1}{2}$ 'inch' needle. Each oyster received $0.1 \mathrm{ml}$ of the parasite suspension or FSW, except for the small Crassostrea gigas and the Ostrea concaphila that received only $0.05 \mathrm{ml}$ due to their. small size. Oysters receiving a similar inoculum were grouped into 1 tank as described above. Oysters were monitored daily and weak or dead individuals were removed and examined for $M$. mackini (method described below). Surviving oysters were examined between 49 and 91 d after inoculation.

In order to determine if warm temperature impedes the development of Denman Island disease in inoculated oysters as it does in oysters exposed by incubation in a homogenate from infected oysters (bath exposure) (Hervio et al. 1996), a preliminary experiment 
was conducted with large Crassostrea gigas. Oysters receiving a similar inoculum were divided into 2 groups. One group $(\mathrm{n}=20)$ was incubated at $10.0 \pm$ $1.0^{\circ} \mathrm{C}$ and the other group ( $\mathrm{n}=38$ ) was incubated at $17.9 \pm 0.1^{\circ} \mathrm{C}$. During the third month of incubation, all oysters held at the cold temperature and 19 oysters from the group at the warm temperature were examined for Mikrocytos mackini. All remaining oysters $(n=19)$ held at the warm temperature were then transferred to $10.2 \pm 0.7^{\circ} \mathrm{C}$ for an additional $84 \mathrm{~d}$ of incubation prior to examination for $M$. mackini. Controls ( $\mathrm{n}=$ 13) were maintained as for the oysters that were initially incubated at the warm temperature and then transferred to the cold temperature.

The effect of incubation at a warm temperature on the development of Denman Island disease in other species of oysters was also tested. Replicate groups of inoculated and control Ostrea edulis, Crassostrea virginica and large C. gigas were incubated in cald (9.2 \pm $2.0^{\circ} \mathrm{C}$ ) or warm seawater $\left(17.9 \pm 0.5^{\circ} \mathrm{C}\right)$. Oysters were maintained and monitored as in other laboratory experiments and surviving oysters were examined between 51 and $59 \mathrm{~d}$ after inoculation.

For all laboratory experiments, all oysters were examined for Mikrocytos mackini using stained tissue imprints of the adductor muscle, palps and/or mantle as described by Hervio et al. (1996). The intensity of infection (as defined by Margolis et al. 1982) was qualitatively evaluated from the number of $M$. mackini observed in oyster tissue imprints. A heavy intensity was assigned to oysters with more than $5 \mathrm{M}$. mackini per field (200 $\mathrm{mm}$ in diameter at $1000 \times$ magnification). All other oysters with $M$. mackini were considered to be lightly infected.

Transmission by field exposure. A more natural field challenge was accomplished by holding oysters on a beach, where Mikrocytos mackini is enzootic, during the spring when transmission occurs. On March 11, 1993, 15 small Crassostrea gigas, 15 large C. gigas, $15 \mathrm{C}$. virginica, 15 Ostrea edulis, and 150 . concaphila were placed in each of 5 plastic perforated trays (Nestier trays, $56 \mathrm{~cm}$ square and $5 \mathrm{~cm}$ high) and covered with plastic predator mesh. A sixth covered tray contained oysters as for the other trays but lacked the 150 . concaphila. The 6 trays were distributed at $30 \mathrm{~m}$ intervals along the beach in Henry Bay (Denman Island, British Columbia) at the $0.75 \mathrm{~m}$ tide level where the disease was first encountered in 1960 (Quayle 1961, Bower 1988). The oysters were left on the beach from March 11 to June 3, 1993. At monthly intervals, each tray was checked and mortalities recorded. On ApriI 8, 1993, 78 resident C. gigas in Henry Bay at the 0.6 to the $0.9 \mathrm{~m}$ tide level were collected and examined for M. mackini. On June 3, 1993, the 6 trays were returned to the laboratory. All re- maining oysters from each tray were placed in separate $50 \mathrm{l}$ tanks and maintained at about $10^{\circ} \mathrm{C}$ as for oysters in the inoculation experiments. Control oysters were kept in the laboratory at about $10^{\circ} \mathrm{C}$ for the duration of the experiment (field exposure and laboratory incubation period)

On September 16, 1993, surviving oysters were examined for the presence of Mikrocytos mackini. Because examination of histological sections is more sensitive for detecting naturally acquired infections of M. mackini in oysters with lesions (Hervio et al. 1996), all oysters with lesions (focal green pustules characteristic of Denman Island disease), all small Crassostrea gigas and all Ostrea concaphila that were too small for the detection of lesions were examined histologically as described by Hervio et al. (1996). The other oysters were examined by the tissue imprint technique as described for the inoculation experiments because this technique was shown to be more sensitive when no lesions are observed (Hervio et al. 1996).

\section{RESULTS}

\section{Transmission by inoculation}

All 4 species of oysters were susceptible to Mikrocytos mackini that was isolated from Crassostrea gigas, and $M$. mackini from both $C$. virginica and Ostrea edulis were infective to exposed oysters (Table 1). In all 4 laboratory experiments reported in Table 1, the prevalence of infection in $C$. virginica and $O$. edulis (from 89 to $100 \%$ ) was greater than in the usual host, C. gigas (from 47 to $66 \%$ regardless of size/age), regardless of the oyster species from which the inoculum originated and the relative number of $M$. mackini inoculated. The same trend occurred for the percentage of oysters that was found moribund during the incubation period and for the percentage of heavily infected oysters. In Expt 2 (Table 1), O. concaphila also had a greater prevalence of infection $(96 \%)$ than $C$. gigas of similar size ( $48 \%$ ) despite the extra $9 \mathrm{~d}$ that the infection had to develop in the $C$. gigas. The same trend occurred for the percentage of moribund oysters found ( 89 versus 17\%) and for the percentage of oysters with a heavy intensity of infection (82 versus $28 \%$ ). Among all control groups, 1 large $C$. gigas, $1 \mathrm{C}$. virginica and $3 O$. concaphila were infected with $M$. mackini, indicating that the oysters had been exposed to this parasite in the field prior to setting up the experiment. However, in all cases, the prevalence of infection and the percentage of heavily infected oysters was considerably greater for the groups exposed by inoculation. 
Table 1. Infectivity of Mikrocytos mackini to various species of Crassostrea and Ostrea following inoculation with a suspension of M. mackini isolated from infected oysters. Inoc. $=$ inoculated

\begin{tabular}{|c|c|c|c|c|c|c|c|c|c|c|}
\hline & \multicolumn{2}{|c|}{$\begin{array}{l}\text { Large C. gigas } \\
\text { Controls Inoc. }\end{array}$} & \multicolumn{2}{|c|}{$\begin{array}{l}\text { Small C. gigas } \\
\text { Controls Inoc. }\end{array}$} & \multicolumn{2}{|c|}{$\begin{array}{l}\text { C. virginica } \\
\text { Controls Inoc. }\end{array}$} & \multicolumn{2}{|c|}{$\begin{array}{l}\text { O. edulis } \\
\text { Controls Inoc. }\end{array}$} & \multicolumn{2}{|c|}{$\begin{array}{l}\text { O. concaphula } \\
\text { Controls Inoc. }\end{array}$} \\
\hline \multicolumn{11}{|c|}{ Expt 1 (from C gigas with 50 per field) } \\
\hline Number of oysters & 30 & 32 & _- & _- & 30 & 35 & 28 & 32 & - & _- \\
\hline Incubation period (d) & 61 & 80 & _- & - & 66 & 77 & 62 & 61 & _- & _- \\
\hline$\%$ moribund & 0.0 & 6.3 & - & - & 0.0 & 20.0 & 0.0 & 90.6 & - & - \\
\hline$\%$ infected & 0.0 & 65.6 & - & - & 0.0 & 100.0 & 0.0 & 100.0 & - & - \\
\hline$\%$ heavily infected ${ }^{\mathrm{b}}$ & 0.0 & 12.5 & - & - & 0.0 & 80.0 & 0.0 & 62.5 & - & - \\
\hline \multicolumn{11}{|c|}{ Expt 2 (from C. gigas with 50 per field) ${ }^{d}$} \\
\hline Number of oysters & 20 & 30 & 30 & 29 & 30 & 30 & 28 & 16 & 27 & 29 \\
\hline Incubation period (d) & 88 & 90 & 88 & 91 & 85 & 85 & 85 & 74 & 82 & 82 \\
\hline$\%$ moribund & 0.0 & 6.7 & 0.0 & 17.2 & 0.0 & 23.3 & 0.0 & 100.0 & 14.8 & 89.7 \\
\hline$\%$ infected & 5.0 & 46.7 & 0.0 & 51.7 & 3.3 & 96.7 & 0.0 & 100.0 & 11.1 & 96.5 \\
\hline$\%$ heavily infected $b$ & 0.0 & 26.7 & 0.0 & 34.5 & 3.3 & 63.3 & 0.0 & 93.7 & 7.4 & 75.9 \\
\hline \multicolumn{11}{|c|}{ Expt 3 (from $C$. virginica with 5 per field) ${ }^{\circ}$} \\
\hline Number of oysters & 20 & 10 & - & - & 20 & 10 & 20 & 10 & - & - \\
\hline Incubation period (d) & 59 & 50 & _- & _ & 59 & 50 & 58 & 51 & _ & _- \\
\hline$\%$ moribund & 0.0 & 0.0 & _- & _- & 0.0 & 0.0 & 0.0 & 0.0 & _- & _- \\
\hline$\%$ infected & 0.0 & 60.0 & - & _- & 0.0 & 100.0 & 0.0 & 90.0 & _- & - \\
\hline$\%$ heavily infected ${ }^{b}$ & 0.0 & 20.0 & - & - & 0.0 & 30.0 & 0.0 & 40.0 & - & - \\
\hline \multicolumn{11}{|c|}{ Expt 4 (from 0 . edulis with 12 per field $)^{a}$} \\
\hline Number of oysters & 20 & 10 & - & - & 20 & 10 & 20 & 9 & - & - \\
\hline Incubation period (d) & 59 & 49 & - & - & 59 & 49 & 58 & 49 & - & - \\
\hline$\%$ moribund & 0.0 & 0.0 & - & - & 0.0 & 0.0 & 0.0 & 66.7 & - & - \\
\hline$\%$ infected & 0.0 & 60.0 & _- & _- & 0.0 & 90.0 & 0.0 & 88.9 & - & - \\
\hline$\%$ heavily infected ${ }^{b}$ & 0.0 & 0.0 & - & - & 0.0 & 0.0 & 0.0 & 66.7 & - & - \\
\hline
\end{tabular}

The preliminary temperature experiment indicated that infections of Mikrocytos mackini did not develop in large inoculated Crassostrea gigas incubated at warm temperatures (about $18^{\circ} \mathrm{C}$ ). Only 2 of 19 inoculated oysters incubated at this warm temperature for 74 d had infections which were barely detectable. However, all 20 inoculated oysters incubated at about $10^{\circ} \mathrm{C}$ for $71 \mathrm{~d}$ were infected and the intensity of infection in 15 of these oysters was heavy. Two of the 19 inoculated oysters incubated at about $18^{\circ} \mathrm{C}$ for $74 \mathrm{~d}$ and transferred to about $10^{\circ} \mathrm{C}$ for a further $84 \mathrm{~d}$ of incubation had light infections, whereas none of the 13 controls treated in a similar fashion were infected.

Mikrocytos mackini was not detected in Crassostrea gigas, C. virginica or Ostrea edulis incubated at warm temperatures for about $55 \mathrm{~d}$ (Table 2). Unlike the 4 laboratory experiments reported in Table 1 , the prevalence of infection in oysters incubated at the cold temperature was similar for all 3 species of oysters (Table 2). Nevertheless, the percentage of oysters that was found moribund during the incubation period and the percentage of heavily infected oysters was greatest for $O$. edulis.

\section{Transmission by field exposure}

During the field and laboratory incubation periods of the field exposure experiment, 25 exposed oysters were either lost $(n=6)$, consumed by crabs $(n=8)$ or decomposed prior to examination $(\mathrm{n}=11)$ and were excluded from the analysis. The distribution of excluded oysters among the species and trays can be easily determined from Table 3 by comparing the number of oysters examined (value in parentheses) with 15 (the original number used for each sample). Four of the exposed oysters (1 Ostrea concaphila and 30 . edulis) became moribund during the laboratory incubation period and all 4 were found to be infected with Mikrocytos mackini. Of the 410 exposed oysters, only 30 became infected with $M$. mackini and over half (19) came from 2 of the 6 trays (Table 3). However, infections were observed in at least $6 \%$ of all 4 species of oysters with $O$. edulis and Crassostea virginica having the highest prevalences 1.2 .4 and $10.0 \%$ respectively). Although all 30 infected oysters had lesions characteristic of Denman Island disease, only 9 (1 0 . concaphila and 80 . edulis) had heavy infections. Thirty-one other oysters representing all species had 
Table 2. Effect of temperature on infectuvity of Mikrocytos mackini to Crassostrea spp. and Ostrea edulis following inoculation with a relative intensity of $20 \mathrm{M}$. mackıni per $200 \mu \mathrm{m}$ diameter field at $1000 \times$ magnification isolated from infected $C$. gigas. Inoc $=$ inoculated

\begin{tabular}{|c|c|c|c|c|c|c|}
\hline & \multicolumn{2}{|c|}{$\begin{array}{l}\text { Large C. gigas } \\
\text { Controls Inoc. }\end{array}$} & \multicolumn{2}{|c|}{$\begin{array}{l}\text { C. virginica } \\
\text { Controls Inoc. }\end{array}$} & \multicolumn{2}{|c|}{$\begin{array}{l}\text { O. edulis } \\
\text { Controls Inoc. }\end{array}$} \\
\hline \multicolumn{7}{|l|}{ Incubated at $9.2 \pm 2.0^{\circ} \mathrm{C}$} \\
\hline Number of oysters & 20 & 19 & 20 & 19 & 20 & 19 \\
\hline Incubation period (d) & 59 & 54 & 59 & 52 & 58 & 51 \\
\hline$\%$ moribund & 0.0 & 10.5 & 0.0 & 5.3 & 0.0 & 47.4 \\
\hline$\%$ infected & 0.0 & 89.5 & 0.0 & 89.5 & 0.0 & 100.0 \\
\hline$\%$ heavily infected ${ }^{a}$ & 0.0 & 57.9 & 0.0 & 42.1 & 0.0 & 73.7 \\
\hline \multicolumn{7}{|l|}{ Incubated at $17.9 \pm 0.5^{\circ} \mathrm{C}$} \\
\hline Number of oysters & - & 20 & - & 17 & - & 20 \\
\hline Incubation period (d) & - & 55 & - & 55 & - & 52 \\
\hline$\%$ moribund & - & 0.0 & - & 0.0 & - & 0.0 \\
\hline$\%$ infected & - & 0.0 & - & 0.0 & - & 0.0 \\
\hline$\%$ heavily infected & - & 0.0 & - & 0.0 & - & 0.0 \\
\hline
\end{tabular}

tissue lesions (focal greenish discoloration in living tissues), but $M$. mackini was observed in neither tissue imprints nor histological sections of these oysters.

Six of the 26 Ostrea concaphila held in the laboratory for the duration of the field exposure (controls) were infected with Mikrocytos mackini. M. mackini was not observed in any of the other 109 control oysters (Table 3). Seventeen percent of the 78 Crassostrea gigas resident in Henry Bay on April 8, 1993 were infected with $M$. mackini.
One factor that provides oyster culturists potential control of Mikrocytos mackini is the sensitivity of this parasite to warm temperatures. The inability of $M$. mackini to develop in oysters (Crassostrea gigas, C. virginica and Ostrea edulis) held at about $17^{\circ} \mathrm{C}$ may explain why this parasite and Denman Island disease have not been reported south of British Columbia, despite the historic exchange of live oysters between British Columbia and Pacific states of the United States to the south (Quayle 1988). Apparently, M. mackini can survive in oysters exposed to these warm temperatures for prolonged periods. In the preliminary temperature experiment reported above and in Hervio et al. (1996), some C. gigas incubated at about $17^{\circ} \mathrm{C}$ for about 3 mo following exposure developed patent infections on return to cold (about $10^{\circ} \mathrm{C}$ ) water. Thus, it is not likely that exposure to warm temperatures can be used as a method of removing $M$. mackini from an infected oyster population.

The apparent greater susceptibility of alternate species of oysters to Mikrocytos mackini suggests that Crassostrea gigas may be the indigenous host of this parasite. However, M. mackini has not been reported from locations outside of British Columbia even though

\section{DISCUSSION}

All species of oysters tested for susceptibility to Mikrocytos mackini became infected regardless of the method of challenge (i.e. by inoculation in the laboratory or by exposure to natural transmission in the fieldj. In most experiments, the severity of infection was greater in species other than the usual host (Crassostrea gigas), suggesting that alternate species of oysters may be more susceptible to infection and the resulting disease. Also, because $M$. mackini from at least 2 of the alternate host species were infective, the threat posed to the culture of oysters in other regions of the world by accidental introduction of this pathogen warrants that precautions be taken when transplanting oysters from British Columbia.
Table 3. Infectivity of Mikrocytos mackini to various species of Crassostrea and Ostrea via natural exposure in the field for $12 \mathrm{wk}$ during the spring followed by $15 \mathrm{wk}$ of incubation in the laboratory at $10^{\circ} \mathrm{C}$. Data recorded as percentage of oysters infected with $M$. mackini followed by the number of oysters examined in parentheses. Control oysters were held in the laboratory for the entire $27 \mathrm{wk}$ period and not intentionally exposed to $M$. mackini

\begin{tabular}{|c|c|c|c|c|c|c|c|}
\hline $\begin{array}{l}\text { Oyster } \\
\text { species }\end{array}$ & Tray 1 & Tray 2 & Tray 3 & Tray 4 & Tray 5 & Tray 6 & Totals \\
\hline \multicolumn{8}{|c|}{ Large C. gigas } \\
\hline Controls & - & - & - & - & - & - & $0(19)$ \\
\hline Exposed & $6.7(15)$ & $13.3(15)$ & $0\{15\}$ & $20.0(15)$ & $0(14)$ & $6.7(15)$ & $7.9(89)$ \\
\hline \multicolumn{8}{|c|}{ Small C. gigas } \\
\hline Controls & - & - & - & _- & - & _- & $0(30)$ \\
\hline Exposed & $0(14)$ & $0(13)$ & $0(15)$ & $0(11)$ & $0(12)$ & $0(14)$ & $0(79)$ \\
\hline \multicolumn{8}{|l|}{ C. virginica } \\
\hline Controls & - & - & - & - & - & _- & $O(30)$ \\
\hline Exposed & $0(15)$ & 6.7 (15) & $6.7(15)$ & $13.3(15)$ & $26.7(15)$ & $6.7(15)$ & $10.0(90)$ \\
\hline \multicolumn{8}{|l|}{ O. edulis } \\
\hline Controls & _. & _- & _- & _- & _- & _- & $0(30)$ \\
\hline Exposed & $0(14)$ & $20.0(15)$ & $0(15)$ & $200(15)$ & $33.3(15)$ & $0(15)$ & $12.4(89)$ \\
\hline \multicolumn{8}{|c|}{ O. conchaphila } \\
\hline Controls & - & - & - & - & - & - & $23.1(26)$ \\
\hline Exposed & $-{ }^{a}$ & $0(14)$ & $7.1(14)$ & $7.7(13)$ & $10.0(10)$ & $8.3(12)$ & $6.4(63)$ \\
\hline Totals & $1.7(58)$ & $8.3(72)$ & $2.7(74)$ & $13.0(69)$ & $15.3(66)$ & $4.2(71)$ & \\
\hline
\end{tabular}


C. gigas is not native to the Pacific coast of North America and was introduced, mainly from Japan (Quayle 1988). The small size of $M$. mackini makes it very difficult to detect, unless the observer is familiar with its morphological characteristics. A micrograph published in an early report on oyster mortalities in Matsushima Bay, Japan (Numachi et al. 1965, Fig. 15 therein) contains structures that appear to be $M$. mackini. Perhaps M. mackini was introduced into British Columbia along with its host $C$. gigas. To verify this speculation, surveys for $M$. mackini will have to be conducted on beachcultured oysters in Japan during the spring.

In British Columbia, the prevalence of Mikrocytos mackini varies yearly in oysters on Henry Bay, Denman Island between 11 and 39\% from 1960 to 1987 , Bower 1988). During the field exposure component of the study reported here, $17 \%$ of the resident Crassostrea gigas on the beach in Henry Bay in April 1993 were infected. Consequently, less than $13 \%$ of each of the oyster species exposed to natural transmission in Henry Bay in 1993 became infected. Variation in the prevalence of infection in oysters between trays (from 1.7 to $15.3 \%$, Table 3 ) suggests that the distribution of the infection in Henry Bay is not uniform. This result supports casual observations noted during surveys for Denman Island disease in oysters (Bower unpubl.).

None of the small Crassostrea gigas developed detectable infections. This result confirms earlier investigations by Quayle (1988), who found oysters less than 2 yr old to be less affected. This apparent lack of infection in young $C$. gigas may be attributable to their small size. Possibly insufficient water was filtered by these small oysters for them to be exposed to infectious Mikrocytos mackini, or the number of infectious forms that were acquired were too few for the infection to be detectable when the experiment was terminated in September 1993. In the field, exposed resident oysters do not develop detectable infections until the following spring (after about a 1 yr prepatent period). To accelerate the development of the disease and to reduce inadvertent losses among experimental oysters left in the field, the oysters were returned to the laboratory after the spring exposure period and incubated at cold temperatures (about $10^{\circ} \mathrm{C}$ ). (In the field, warm summer temperatures delay the development of the infection; Hervio et al. 1996) The $15 \mathrm{wk}$ incubation period in the laboratory may have been too short for the development of patent infections in oysters that were exposed to very few in:ective forms. Nevertheless, 15 wk was sufficient for the development of infections in some individuals of all species tested, thus confirming the susceptibility of all species under natural conditions

The occurrence of Mikrocytos mackini in control groups of oysters was not unexpected because all oysters used in this study originated from beaches in
British Columbia. However, this was the first time that this parasite has been observed in Crassostrea virginica and Ostrea concaphila from the field. From 1903 to 1940, extensive attempts were made to introduce $C$. virginica into at least 5 locations in southern British Columbia (Quayle 1988). However, a remnant population survives in only 1 location: the upper river estuaries of Boundary Bay. In areas of higher salinity at this location, C. gigas cohabits with $C$. virginica and could have been the source of infection for the $C$. virginica in one of the control groups (Table 1). Denman Island disease may be one of the factors that currently limits the expansion of $C$. virginica populations in British Columbia.

Prior to 1940, a fishery for Ostrea concaphila existed and attempts to culture this species were made in British Columbia. However in the early 1940s, a drastic drop occurred in $O$. concaphila populations in Boundary Bay and Ladysmith Harbor, British Columbia, for 'no perceptible reason' (Quayle 1988). In the decade prior to the $1940 \mathrm{~s}$, millions of Crassostrea gigas seed had been imported into British Columbia from Japan. Perhaps Mikrocytos mackini had inadvertently arrived in British Columbia with this seed and had precipitated the drastic reduction in $O$. concaphila populations. Although $O$. concaphila still occurs in regions where M. mackini is considered enzootic, $O$. concaphila is no longer abundant and is rarely found where C. gigas is cultured. A similar scenario could occur with other endemic species of oysters in other parts of the world if M. mackini is inadvertently introduced during transplantations of the usual host C. gigas.

\section{LITERATURE CITED}

Bower SM (1988) Circumvention of mortalities caused by Denman Island oyster disease during mariculture of Pacific oysters. Am Fish Soc Spec Publ 18:246-248

Farley CA, Wolf PH, Elston RA (1988) A long term study of 'microcell' disease in oysters with a description of a new genus, Mikrocytos (g. n.), and two new species, Mikrocytos mackini (sp. n.) and Mikrocytos roughleyi (sp. n.). Fish Bull US 86:581-593

Hervio D, Bower SM, Meyer GR (1996) Detection, isolation, and experimental transmission of Mikrocytos mackini, a microcell parasite of Pacific oysters Crassostrea gigas (Thunberg). J Invertebr Pathol 67:72-79

Margolis, L, Esch GW, Holme JC, Kuris AM, Shad GA (1982) The use of ecological terms in parasitology (Report of an ad hoc committee of the American Society of Parasitologists). J Parasitol 68:131-133

Numachi K, Oizumi J, Sato S, Imai T (1965) Studies on mass mortality of the oyster in Matsushima Bay. III. The pathological changes of the oyster caused by Gram-positive bacteria and the frequency of their infection. Bull Tohoku Reg Fish Res Lab 25:39-47

Quayle DB (1961) Denman Island disease and mortalities, 1960. Fish Res Bd Can Manusc Rep Ser Biol 713: 1-9

Quayle DB (1988) Pacific oyster culture in British Columbia. Can Bull Fish Aquat Sci 218:1-241 